\title{
Study on New Teaching Model of "Statistics"
}

\author{
Tingting Chen \\ Xijing University \\ Xi'an, China 710123
}

\begin{abstract}
Statistics" occupies a very important position in the colleges and universities of finance and economics in China. As one of ten core courses, the major financial colleges, teachers, parents and students have paid much attention to the course of "statistics". However, the teaching effect of the current course of "statistics" isn't ideal. There are some very important issues in this process. With the analysis of teaching problems and teaching experience, this paper has studied the new teaching model of "statistics" course. And then, it could make contribution to the education.
\end{abstract}

Keywords-statistics; teaching model; experiential teaching model; classroom teaching quality; innovation

\section{INTRODUCTION}

With the rapid development of China's market economy, the application of statistical analysis method is used more and more widely in the individual investment and decisionmaking, the development and management of enterprise and the management of national economy. The statistical analysis method has become important application tool in current socio-economic areas of China. As one of methodological subjects, "statistics" has great advantages in collecting, analyzing and collating the economic data. At present, "statistics" is the core basic course of major financial colleges in China.

\section{The Problems IN THE TEACHING Process OF "STATISTICS"}

According to the author's teaching experience, it finds that there are some unavoidable problems in the teaching of "statistics". If it wants to improve the teaching quality of "statistics", it must start to analyze these obstacles and make exploration of new teaching model on this basis.

\section{A. The Teaching Mode Is Undeveloped}

There are many problems in the current teaching of "statistics", the most important of which is the underdevelopment of the teaching model. Many teachers still take the old teaching mode of the traditional lecture, and the teaching concept is undeveloped. Many teachers still take the students as the object of knowledge indoctrination. And teachers are always the subjects of the education. [1] The teaching forms are single. The content is boring. And the teachers just dictate the knowledge of the textbooks. The

Project Title: The study on Construction and Practice of Teaching Mode of "Statistics"

Project Number: GZJGYB1609 teacher has finished the teaching process of the knowledge. However, the students are confused and sleepy. At present, many teachers have used multimedia teaching aids in the teaching of "statistics". However, it cures the symptoms not the disease. There are still dull and cramming teaching situation. Many teachers just use multimedia equipment to show the teaching content. Usually, the teaching content is handwritten on the blackboard. Actually, the teachers still talk about the theoretical knowledge, and the students just listen to the teachers. It hasn't changed the teaching model. The only way for students to improve their practical ability is classroom practice and after-school homework. The teaching is separated from the practice seriously. [2] In this teaching mode of cramming education, the interaction between teachers and students is only on classroom questions. There is little communication between teaching and learning. And there is less interaction between students. In this case, the teachers can't really understand whether the students master the knowledge content or the mastery degree. Students aren't willing to take the initiative to express the confusion or problems to the teachers in the learning process.

\section{B. The Lack of Capacity Training}

The teachers really work hard in the teaching model. And it also has really aroused the enthusiasm and interest of students. However, it can't combine the theory with practice. In the teaching process, it just talks about stratagems on paper. It can't stimulate students to explore the greater interest and motivation. For the abstract and boring teaching content, some students think that it is difficult to learn. The teachers can do nothing to solve this problem. At present, the teachers put emphasis on explaining the statistical theorem in the teaching process. The students master the statistical formula. And the students would have the practice training. Students still have learning through rote memorization. The teachers also pay little attention to cultivate students' learning ability. [3] It has caused some situation. The students can clearly remember the statistical formula and statistical theory. However, they can't use these formulas and theories to solve practical problems. The ability to link the theory with practice is poor. The students can't learn to use these formulas and theories in the practice. It is clearly contrary to the nature of education. What's more, students casually deal with homework. In the classroom, they don't have the learning. In the final examination, the students would have worked hard for a period of time to take the exam. In other words, the teaching still puts emphasis on scores. The students still only focus on scores. It reflects the teaching strategy of teachers from one side. Nowadays, the society is 
more stringent on the requirements of talents. The colleges and universities should cultivate the talents with the comprehensive application ability of practical application ability, teamwork ability, innovation ability and learning ability to the talent market. For this teaching goal, it still has a long way to go.

\section{StUdy On NeW TeAChing Model of "STAtistics"}

According to the survey, it shows that the human brain remembers about 10 percent of the reading information, about 20 percent of voice information and about eighty percent of their own experience information. In view of the teaching problems in the teaching of "statistics", the author puts forward the new model of "experiential teaching" according to the teaching experience. Students follow the teaching model to have the immersive experience. With the experience, it would achieve high degree of memory of knowledge. The main design content of new model of socalled "experiential teaching" is to allow students to participate in activities related to the construction of clear perceptual knowledge. And according to these activities, the students would form their own subjective sense of attitude and feelings. And then, the students could make judgement with more subjective willingness, acquire and comprehend knowledge. In the end, the students could form more positive and healthy values and emotional attitudes. "Experiential teaching" is a new model for students to experience, comprehend the learning process. [4] The students can obtain independent creation, cooperation and mutual assistance, cognitive improvement. The students are unconsciously influenced to make changes from passive learning to active exploration. It would improve teaching quality and achieve teaching objectives. The new model of "experiential teaching" is divided into three teaching stages: pre-class mobilization, to plan the course and the implementation of the program.

\section{A. Pre-class Mobilization}

The main purpose of the so-called pre-class mobilization is to enable students to understand the main teaching method of this course. At this stage, the teachers should inform the students of the teaching features and methods of the teaching content in advance. And the teachers should put some requirements for the students and mobilize them to actively participate in all aspects of the new teaching model. [5] Of course, it isn't easy at this stage. After all, students have adapted to the traditional teaching model for many years. The students need to spend a lot of time to participate in the new teaching model. Due to the exclusion psychology of new things, a part of students don't want to participate in the new teaching model actively. At this time, the teachers need to spend time to make the explanation on the significance of the implementation of the new teaching model for the students. And the teachers should tell the students how they can do it and what they need to prepare in advance. Then, the students would know what they can harvest. After the mobilization, most of the students are willing to try and participate in these activities.

\section{B. To Plan the Course}

The course planning is the soul of new model of the whole "experiential teaching". he quality of the course planning is high. And then, the whole course has been achieved half of success. The planning courses require the teachers to carry out the overall arrangement and design of the teaching content and teaching courses from the requirements of the teaching syllabus of "statistics" . [6] The arrangement must consider every section of each chapter and every question. The teachers should understand the doubts put forward by the students in this session in advance. The teachers must know how to guide students to think. And the teachers must know how to answer these questions, etc. They have to make detailed plan.

\section{The Implementation of the Program}

After the completion of the course planning, it would enter into the implementation of the program. The implementation of the program is important for new model of "experiential teaching". At this stage, the author mainly used the context teaching method to assist the teaching and the implementation of curriculum design. For example, the teachers should investigate destructive tests from the perspective of fluorescent lamp test in sample teaching. It should combine the teaching with the practice of life. Naturally, the teachers should mention that we can't waste electricity, and we should cherish the classroom fluorescent. It should unite the theory with the practice. And then, the students are willing to accept it. [7] The teachers can combine the specific teaching content with different learning levels of the students to create appropriate teaching situation. The teachers should use vivid and intuitive teaching context to bring the students into a specific learning atmosphere. With the strong sensory stimulation, the students can deepen memory of knowledge.

For example, the first half of the content of current "statistics" textbooks is relatively simple. The students can make the preparation for explaining this part. As for the selection of the lecturer of each lesson, the teachers can make decision on the basis of random sampling principle. According to the multi-stage sampling, type sampling, isometric sampling, simple sampling, repeated sampling, non-repeat sampling, etc., the students can fully experience the randomness of the samples. The producing method of the lecturer of each lesson is random. Every student can't expect who the speaker is before the class. The students will be very serious to prepare lessons, to search information in the library, and to discuss with other students and so on. In this way, every student can master the knowledge soundly. When a student acts as a speaker, the teacher can't keep out of the affair. The teachers also need to prepare lessons. And then, the teachers can correct the explanation and the understanding level of the students in time. It can help students better explain and master the knowledge. And to make the students prepare the teaching is a unique situational teaching method essentially. In this situation, the students are both the audience and the actors. Through the immersive preparation for lectures, the students can exercise themselves. And then, the classroom atmosphere is active. It also 
enhances the quality of classroom teaching, and the students can remember the knowledge deeply. Of course, teachers can also use the real story in the books, real events in life and the current hot events to create the situation to assist the teaching. For example, teachers can use the previous movie named "Wreaths at the Foot of the Mountain" to teach the sampling. It is extremely necessary to tell students about the importance of sampling in quality inspection because of the unfortunate sacrifice of a blind shell. Of course, teachers can also give students a variety of successful business and personal cases with the use of statistical techniques. The students can see the contribution of statistics. It can stimulate students' enthusiasm.

It has many ways to create the context. It can use multimedia equipment. It also can dictate directly. With the use of situational teaching, the students can understand the meaning of cherishing. The students can experience how to learn the knowledge; also can understand the important role of learning statistical knowledge and how much contribution it will contribute to the world. So, students will be more willing to take the initiative to study, explore and improve the quality of teaching.

\section{The AdVANTAGES OF NeW MOdEL OF "EXPERIENTIAL TEACHING "}

According to new model of "experiential teaching", it can stimulate students' enthusiasm and interest in learning through their experiences. And then, students would take the initiative to explore and learn actively. There are great differences between traditional teaching model and new teaching model. In the new model of "experiential teaching", the students are dominant in the teaching process. And the students can effectively play their subjective roles. And then, students are responsible for their own learning. This is the first. Secondly, the new model of "experiential teaching" pays attention to the application of the knowledge. It should combine the theory with practice. And then, the students know which kind of the occasion their knowledge can be used. And the students can analyze the actual cases. In the teaching process, it stimulates the learning interest of students. And the students are willing to take the initiative to learn. Thirdly, it teaches through lively activities in the new model of "experiential teaching". It is different from the traditional boring teaching methods. In the new model of "experiential teaching", it attaches more importance to that the students can learn the knowledge in relaxed and pleasant learning atmosphere. Teachers will play their own ability to innovate, and do their best to explain the content with the way to stimulate the learning enthusiasm of students. Students can get knowledgeable when they are fully motivated. Of course, the enjoyment of the new model of "experiential teaching" is not only created by the teachers unilaterally. The students also can experience the sense of accomplishment and fun through exploring and solving the problems.

\section{CONCLUSION}

In summary, the author has studied a set of new teaching model of "experiential teaching" to solve the teaching problems in the teaching process of "statistical". It has proved that this teaching model has played great role in improving initiative, enthusiasm and interest of students' learning. Students have the learning in the more relaxed and happy atmosphere. And the students can really feel immersive happiness. It has greatly improved the quality of teaching. Sukhomelinski, a Russian educator once said that the lack of a relaxed atmosphere in classroom teaching would make the learning be the heavier burden of students. And conversely, it would make learning be more interesting. The new teaching model of "experiential teaching" is such a teaching model. Students are encouraged to learn. And they can learn the knowledge efficiently. Also, they can apply the knowledge in the practice.

\section{REFERENCES}

[1] Xiao Pan, Su Jing. Research on the teaching reform of applied statistics in the context of innovation and entrepreneurship education [J/OL]. Science and Technology Information, 2016,14 (13): 98-99, 101 .

[2] Wang Yong. Research on teaching reform of economic statistics course in colleges and universities [J]. China Management Information, 2015,18 (21): 237-238. [2017-09-12].

[3] Chen Xiufen. Reflections on the teaching reform of statistical courses in the big data age [J]. Journal of Higher Education, 2015, (20): 106107. [2017-09-12].

[4] Hu Mingxing, Chen Wenhui. The design of the teaching case system of "statistics" [J]. China Forestry Education, 2015,33 (05): 44-47. [2017-09-12].

[5] He Lihong. Reflection and practice of professional statistics teaching reform of management [J]. Higher Science Education, 2014, (02): 119-122. [2017-09-12]

[6] Shen Huimin. Application of case teaching in the teaching of professional statistics course [J]. China Management Information, 2012,15 (23): 94-96. [2017-09-12].

[7] Zhang Zhaohui. Discussion on teaching reform of statistics course of economics and management specialty-Taking Putian university as an example [J]. Technology and Industry, 2010,10 (12): 109-112, 140 [2017-09-12]. 